\title{
Shewanella putrefaciens - a new opportunistic pathogen of freshwater fish
}

\author{
Ewa Paździor \\ Department of Fish Diseases, \\ National Veterinary Research Institute, 24-100 Pulawy, Poland \\ ewa.pazdzior@piwet.pulawy.pl
}

Received: May 17, 2016

Accepted: August 31, 2016

\begin{abstract}
In recent years, Shewanella putrefaciens, commonly known as a halophilic bacteria, has been associated with serious health disorders in freshwater fish. Therefore, it has been described as a new aetiological agent of the disease, named shewanellosis. S. putrefaciens is a heterogeneous group of microorganisms, belonging to the Alteromonadaceae family. Based on different criteria, three biovars and biogroups as well as four genomic groups have been distinguished. The first infections of S. putrefaciens in fish were reported in rabbitfish (Siganus rivulatus) and European sea bass (Dicentrarchus labrax L.). Outbreaks in farmed fish were reported in Poland for the first time in 2004. The disease causes skin disorders and haemorrhages in internal organs. It should be noted that $S$. putrefaciens could also be associated with different infections in humans, such as skin and tissue infections, bacteraemia, otitis. Investigations on pathogenic mechanisms of $S$. putrefaciens infections are very limited. Enzymatic activity, cytotoxin secretion, adhesion ability, lipopolysaccharide (LPS), and the presence of siderophores are potential virulence factors of $S$. putrefaciens. Antimicrobial resistance of $S$. putrefaciens is different and depends on the isolates. In general, these bacteria are sensitive to antimicrobial drugs commonly used in aquaculture.
\end{abstract}

Keywords: freshwater fish, Shewanella putrefaciens, pathogenicity, virulence factors.

\section{Introduction}

Shewanella putrefaciens is commonly known as halophilic bacteria having an important role in the spoilage process of frozen food products such as fish, beef, and poultry meat $(6,11,13,14,36)$. A significant impact of this bacterium on human health has also been noted, with a total of 260 health disorders described over the last 40 years, clearly indicating the potential hazard it poses $(17,45)$.

In recent years, $S$. putrefaciens has been associated with serious health disorders in fish, and therefore these bacteria have been described as a new aetiological agent of the disease, named shewanellosis (28). The first fish infections caused by S. putrefaciens were reported in marine species $(22,38)$. In freshwater fish, the disease outbreaks were described for the first time in Poland in 2004 (24). Since then, serious health problems have been observed in various freshwater fish species $(24,33,34,35,37)$. The most interesting fact is that $S$. putrefaciens, considered as halophytic bacteria, has an ability to adapt to freshwater environment.

The aim of this review is to present the current state of knowledge concerning $S$. putrefaciens as a new aetiological agent of fish disease.

Taxonomy. S. putrefaciens is a gammaproteobacterium belonging to the Alteromonadaceae family (7). This bacterium, isolated for the first time in 1931, was initially classified as Achromobacter putrefaciens or Pseudomonas putrefaciens (26), and finally, in 1985, as Shewanella putrefaciens (27).

Different properties were used to characterise S. putrefaciens strains (Table 1). Based on growth conditions, three biovars of these microorganisms have been distinguished. Bacteria classified into biovars 1 and 3 include mainly psychrophilic strains, which have no ability to grow in $6 \%$ sodium chloride, in contrast to mesophilic isolates classified into biovar 2 which grow in higher concentrations of this compound (12). 
Table 1. Classification of S. putrefaciens strains

\begin{tabular}{lllll}
\hline Properties & Growth conditions (12) & $\begin{array}{l}\text { Biochemical properties } \\
(20)\end{array}$ & $\begin{array}{l}\text { DNA-DNA hybridisation } \\
(31)\end{array}$ & $\begin{array}{l}\text { 16S rRNA gene } \\
(7,33)\end{array}$ \\
\hline \multirow{2}{*}{ Taxon } & biovar 1, 2,3 & biogroup 1, 2,3 & $\begin{array}{l}\text { Owen's genomic groups } \\
\text { I, II, III, IV }\end{array}$ & group I, II \\
\hline
\end{tabular}

According to another classification based on the biochemical properties of $S$. putrefaciens strains, the bacteria have been divided into three biogroups. Biogroup 1 is represented by the isolates which exhibited the ability to produce acid from maltose and sucrose, as opposed to the strains classified into biogroups 2. All isolates belonging to biogroup 3 show the ability to produce only acid from maltose (20).

Based on DNA-DNA hybridisation, S. putrefaciens has been divided into four clearly separated Owen's genomic groups (I-IV) (31). The first genomic group (I) includes isolates of $S$. putrefaciens sensu stricto, which contain 43-45 mol \% G+C. Biochemical properties of the isolates representing this genomic group are similar to those classified previously into biogroup 2 (20). Basic composition of the strains classified into genomic group III ranges from 46 to 49 mol \% G+C, and their properties are similar to strains classified into biogroup 1 (20). However, nomenclature of genomic group III is still not clear, and therefore these strains are defined as S. putrefaciens group III. Genomic groups II and IV were reclassified as $S$. baltica (47) and S. algae (30), respectively.

Analysis of the 16S rRNA gene indicated that the isolates of $S$. putrefaciens were placed with other species of the genus Shewanella, such as S. baltica, S. oneidensis, and S. frigdimarina (7). Afterwards, it occurred that $S$. putrefaciens strains were heterogeneous. Analysis of the $16 \mathrm{~S}$ rRNA gene sequence showed that the strains qualified into Owen's genomic group I, represented by ATCC 8071, and group III represented by a strain ATCC 8073, are located in two separate sub-groups $(7,31)$. Moreover, our own studies, based on 16S rRNA gene sequences, subdivided the isolates collected from freshwater fish into two analogous sub-groups (33). The first subgroup (I) includes the strains isolated from fish exhibiting clinical signs of the disease, while the subgroup II was represented by the strains collected mainly from wild and ornamental fish. In addition, our analysis of the conservative region of $16 \mathrm{~S}$ rRNA gene confirmed that $S$. putrefaciens isolated from freshwater fish represented at least three different species, but only one belonged to $S$. putrefaciens sensu stricto (unpublished data).

Occurrence. S. putrefaciens belongs to a heterogeneous group of microorganisms adapted to different ecosystems. These bacteria were considered as halophilic microorganisms, isolated mainly from marine environment, brackish water, and sediments (8, 32). Currently, S. putrefaciens group is spreading to different ecosystems, including freshwater environments $(7,24)$. The bacteria have been isolated from a number of environmental sources, such as ponds, lakes, estuaries, soil, and crude oil (7, 29, 39).

S. putrefaciens is commonly known as a spoilage microorganism of seafood, e.g. fish and shellfish, as well as poultry and beef products stored under refrigerated conditions $(7,36,43)$. Furthermore, the bacteria form volatile compounds, which are responsible for odour of spoiled fish (7). In healthy fish, S. putrefaciens colonises the gills $(2,32)$, and similarly to other opportunistic bacteria (Aeromonas sp., Pseudomonas sp.) is a part of physiological flora of marine and freshwater fish species $(1,2,32)$.

These bacteria are also isolated from humans. The most common disorders caused by $S$. putrefaciens are skin and tissue infection, bacteraemia, otitis, and abdominal or biliary tract infections. Less frequently, $S$. putrefaciens is associated with infections of the eyes, respiratory tract, bones, urinary tract, or heart $(17,45)$. Pneumonia caused by these bacteria in premature babies has been also reported. Nevertheless, most health disorders affect patients with a weakened immune system (40). Humans are usually infected through skin contact with water, especially when the former has wounds or ulcers (10). However, many infections have not been correlated with water and were reported in hospitalised patients $(5,45)$.

Morphology, growth characteristics, and biochemical properties. Bacteria of $S$. putrefaciens group are Gram-negative and rod-shaped measuring $0.5-1.0 \mu \mathrm{m} \times 1.5-2.0 \mu \mathrm{m}$. The bacteria show mobility due to the presence of single polar flagella. $S$. putrefaciens does not produce capsules or spores. Colonies are round, shiny, and orange in colour (Fig. 1), with the size ranging from $1 \mathrm{~mm}$ to $2 \mathrm{~mm}$ (7).

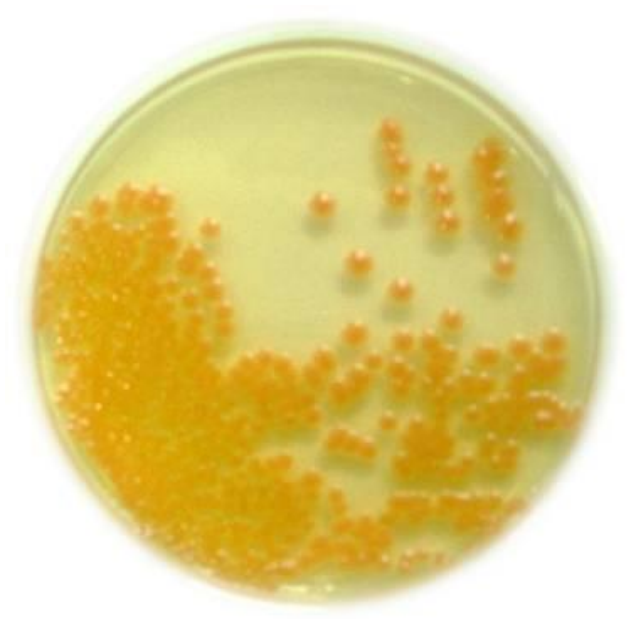

Fig. 1. Colonies of S. putrefaciens 
S. putrefaciens is facultative anaerobe and the optimum growth temperature varies between 4 and $37^{\circ} \mathrm{C}(7,20$, $22,24,35)$. The presence of sodium chloride is necessary to culture $S$. putrefaciens. However, some strains do not require this compound, which shows the adaptability of these microorganisms to the freshwater environments $(7,20)$.

Generally, S. putrefaciens is oxidase positive, hydrolyses gelatine, and reduces nitrate to nitrite $(7,8$, 17, 22, 33, 35). However, the differences between some of the biochemical properties, such as production of acid from arabinose $(7,8,17,20,24,33)$, decarboxylation of ornithine $(20,22,24,33,35)$, or citrate assimilation $(7,8,33)$, were observed. Selected properties of $S$. putrefaciens strains are presented in Table 2.

Table 2. Characteristics of $S$. putrefaciens strains

\begin{tabular}{ll}
\hline Gram staining & - \\
\hline Morphology of the cells & rod \\
\hline Motility & + \\
\hline Production of the spores or capsules & - \\
\hline Oxygen requirements & $\begin{array}{l}\text { facultative } \\
\text { anaerobe }\end{array}$ \\
\hline Growth temperature & $4-37^{\circ} \mathrm{C}$ \\
\hline Oxidase & + \\
\hline Reduction of NO 3 to NO ${ }_{2}$ & + \\
\hline Ornithine decarboxylase & $\mathrm{v}$ \\
\hline Citrate assimilation & $\mathrm{v}$ \\
\hline H ${ }_{2}$ S production & + \\
\hline Gelatin hydrolysis & + \\
\hline Esculin hydrolysis & $\mathrm{v}$ \\
\hline Urease hydrolysis & - \\
\hline Production of acid from arabinose & $\mathrm{v}$ \\
\hline $\begin{array}{l}\text { Production of acid from glucose, mannitol, } \\
\text { inositol, sorbitol, } \\
\text { rhamnose, melibiose, and amygdalin }\end{array}$ & - \\
\hline Tryptophan deaminase & - \\
\hline Indole production & - \\
\hline Voges-Proskauer & $\mathrm{v}$ \\
\hline $\begin{array}{l}\text { Assimilation of glucose, arabinose } \\
\text { potassium gluconate, and capric acid }\end{array}$ & - \\
\hline Assimilation of mannose, mannitol & - \\
\hline & \\
\hline
\end{tabular}

negative: - , positive: + , variable: $\mathrm{v}$

These microorganisms show the ability to convert inorganic or organic compounds and metals such as iron, manganese, chromium, and uranium, during anaerobic respiration (7, 29). In addition, S. putrefaciens reduces sulphate and sulphur to hydrogen sulphide, and also trimethylamine oxide to trimethylamine. These components are responsible for fishy odour (7).

Susceptible host species and clinical signs of fish disease. $S$. putrefaciens infections have been reported in different freshwater fish species, e.g. loach (Misgurnus anguilticaudatus) in China (35), siberian sturgeon (Acipenser baerii) and hybrid sturgeon (Huso huso x Acipenser baerii) in North Bulgaria (37). In Poland, the disease has been diagnosed in common carp (Cyprinus carpio L.), rainbow trout (Oncorhynchus mykiss) (24, 33), as well as in wild population of fish, such as silver carp (Hypophthalmichthys molitrix), sander (Sander lucioperca), and brown trout (Salmo trutta m. trutta) (33). Furthermore, health disorders caused by $S$. putrefaciens have been noted in ornamental fish imported to Poland from Africa: koi carp (Cyprinus carpio L.) and slender krib (Pelvicachromis taeniatus) (33).

The mortality of farmed fish associated with S. putrefaciens infections was estimated at $33 \%$, while the challenge test showed $85 \%$ mortality $(24,33,35$, 37). The intensity of shewanellosis is usually dependent on the kind of bacterial isolate. The disease is generally manifested by ulcerative and necrotic lesions on the skin (Figs 2 and 3). Clinical signs may include disorders such as lethargy, dark discoloration of the skin, swollen anus (Fig. 4), and necrosis of the gills. Internally, gross lesions may include haemorrhage in the kidneys and spleen as well as petechiae in the swim bladder $(24,33,35,37)$. In most cases, S. putrefaciens was isolated together with other species, e.g. Aeromonas sp. and Pseudomonas sp. (33), Listonella sp. (35), and Staphylococcus warneri (37). In marine fish, such as rabbitfish Siganus rivulatus and European sea bass (Dicentrarchus labrax), S. putrefaciens caused health disorders, also leading to mortality $(22,38)$. The clinical signs of affected fish included lethargy, ulcers on the dorsal part of the body, and paleness of internal organs $(22,38)$.

Outbreaks in farmed fish generally occur in spring, when water temperature ranges from 7 to $10^{\circ} \mathrm{C}$ (33). Furthermore, our studies showed the ability of S. putrefaciens to grow in pond water at temperature range of $5-15^{\circ} \mathrm{C}$. In addition, it was found that these microorganisms inhibit other bacteria present in freshwater. This indicates the correlation of infections in fish with low water temperatures (unpublished data).

Virulence factors. Research on the pathogenic mechanisms of $S$. putrefaciens is very limited. Factors determining penetration and proliferation of S. putrefaciens, or tissue damage in the infected organisms have not been described yet. Therefore, potential virulence factors, which include enzymatic activity, cytotoxins secretion, adhesion ability, lipopolysaccharides (LPS), and the presence of siderophores, are analysed in this review.

Enzymatic properties play an important role in the metabolic pathways of microorganisms, determining their pathogenicity, and consequently, spread of bacteria in the organisms. Hydrolytic enzymes, especially proteases, which contribute to tissue damage as well as inhibition of the host immune response, have a significant role in pathogenesis (44). 


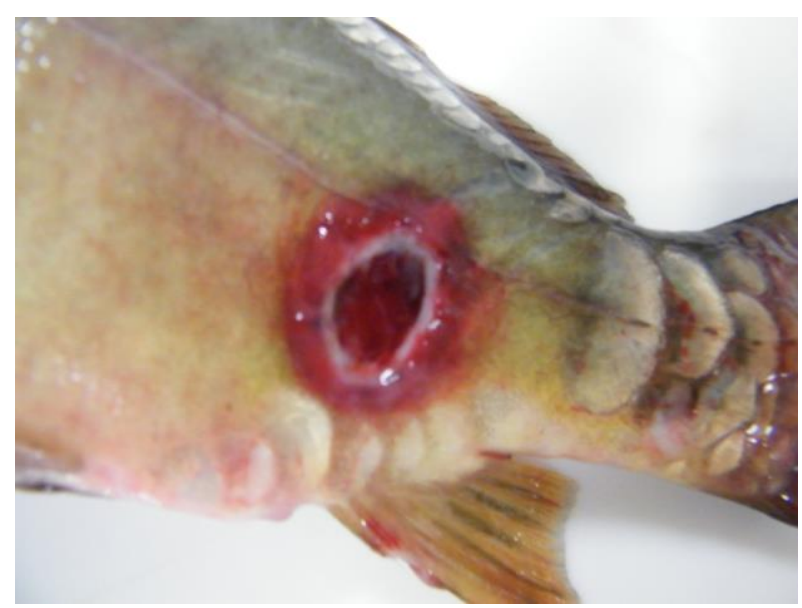

Fig. 2. Common carp - necrotic lesions and ulcers on the skin

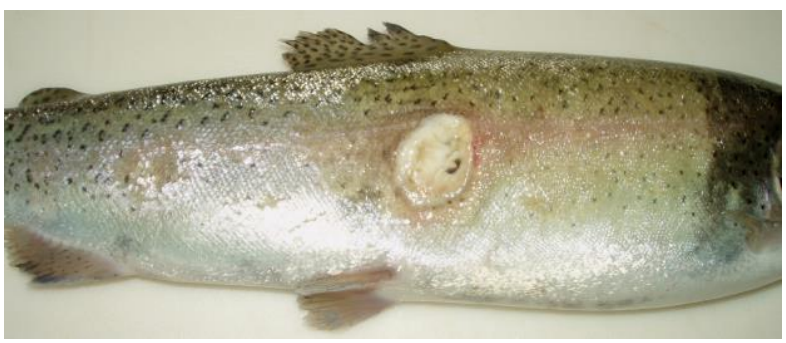

Fig. 3. Rainbow trout - necrotic lesions and ulcers on the skin

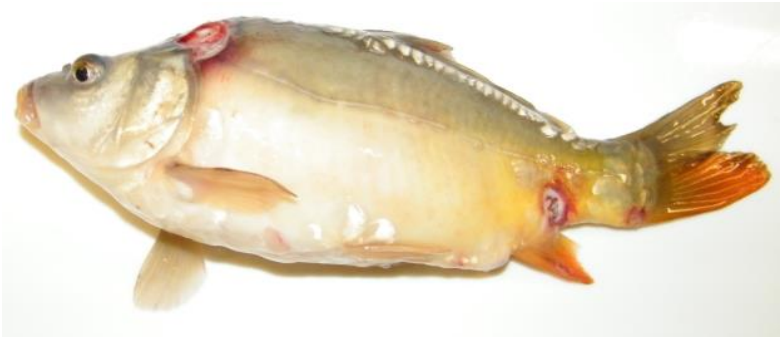

Fig. 4. Common carp - swollen anus and skin ulcers

For example, bacteria of the genus Aeromonas that cause fish infections demonstrate lipolytic and proteolytic activity that defines their pathogenicity (44). S. putrefaciens strains are characterised by the high activity of acid and alkaline phosphatases, esterase, leucine arylamidase, and naphtholAS-BI phosphohydrolase. However, only some isolates produce valine arylamidase, trypsin, chymotrypsin, and $\mathrm{N}$-acetyl- $\beta$-glucosaminidase $(20,33)$. Furthermore, proteolytic (20,33) and lipolityic (33) activity of S. putrefaciens were also determined.

Another important property of the bacteria is secretion of cytolysins, e.g. haemolysins. Most strains of $S$. putrefaciens are not able to produce haemolysins $(17,24,30)$; however, some isolates show this ability $(20,22,36,46)$, which indicates the diversity of these microorganisms. Haemolysis was observed mainly in bacteria classified into Owen's genomic group III (31).

The bacteria produce specific proteins that allow colonisation of host tissues by microorganisms. Bacterial fish pathogens secrete proteins, called adhesins, determining their pathogenicity $(9,23)$. Some isolates of $S$. putrefaciens have the ability to adhere to human epithelial type 2 cells (HEp-2) (20). Moreover, $S$. putrefaciens adhere and form biofilms on steel surfaces due to iron reduction (3). Bacterial adhesion ability is a significant problem in food industry, as it causes difficulties in their elimination from the production areas, adversely affects the quality of food, and may lead to diseases in humans. From the perspective of aquaculture, ability of $S$. putrefaciens to adhere to various tools and equipment at fish farms may be a source of fish infections. Since most bacterial fish pathogens, including $S$. putrefaciens, are facultative and may cause the diseases when environmental conditions become unfavourable, it poses a serious problem.

Lipopolysaccharide (LPS) is a component of the outer membrane of Gram-negative bacteria, which consists of three regions: the most conservative lipid A, core polysaccharide, and O-specific antigen. Depending on the length of O-specific chain, two types of LPS are observed: the smooth LPS (S-LPS) which contains the $\mathrm{O}$-antigenic side chain and rough LPS (R-LPS), which does not contain side chains of the O-antigen or they are reduced (4). R-LPS without O-chains was described in $S$. putrefaciens $(21,28)$. The reduced lipopolysaccharide structure allows for better adhesion of bacteria to the iron-containing surface, and therefore more efficient use of this metal as an electron acceptor in respiration. The core of LPS has high concentrations of carboxyl and phosphoryl sites, which indicate the polarity, and contribute to the interaction with metal ions (21). In addition, the LPS of $S$. putrefaciens predisposes these bacteria to form biofilms on iron surface, and also enables to use this metal in their metabolic pathways. On the other hand, the O-antigen determines pathogenicity of some bacteria protecting them from the host immune response (44). Moreover, O-specific chains define serotypes due to the presence of somatic antigens characteristic for individual strains (19). Therefore, the reduction of O-specific chain in S. putrefaciens causes difficulties in serological differentiation of these bacteria based on somatic antigen.

Siderophores represent potential virulence factors of $S$. putrefaciens. These compounds acquire iron to the bacterial cells under iron deficient conditions. This metal is necessary in such metabolic processes as respiration, DNA synthesis or gene regulation, and it constitutes the component of many enzymes secreted by bacteria. Moreover, siderophores are important pathogenic factors, which bind iron in the host cells, and transport it into bacterial cells (4). Siderophores are low molecular mass compounds divided into three major classes: hydroxamates, phenolates, and carboxylates (16). S. putrefaciens produces hydroxamate-type siderophores $(15,20)$, e.g. putrebactin, which are formed during decarboxylation of L-ornithine $(25,41,42)$. The hydroxamate compounds are characterised by lower affinity to iron 
in comparison with phenolates produced by Pseudomonas sp. isolated commonly together with S. putrefaciens. Therefore, S. putrefaciens may be inhibited by these microorganisms under iron-limited conditions (15).

Antibiotic resistance. Resistance of $S$. putrefaciens to antimicrobial agents depends on the source of isolates. In recent years, studies have been performed on sensitivity of different bacterial strains collected from freshwater $(24,33,35,37)$ and marine fish (22), as well as shellfish (18) and also humans (45), against various chemotherapeutic agents. A common feature of all isolates is the sensitivity to quinolones $(18,24,33,35$, $37,45)$. The majority of isolates showed sensitivity to tetracycline $(20,24,33,37,45)$, although the isolates from marine fish were resistant to this group of antimicrobial substances (22). Bacteria collected from fish and most human isolates showed sensitivity to sulphonamide and trimethoprim combinations $(33,45)$. Strains isolated from marine as well as from freshwater fish were resistant to sulphonamides $(33,35)$. Resistance to penicillins was usually observed in $S$. putrefaciens $(18,24,33,35,37)$; however, isolates collected from marine fish showed sensitivity to this antibiotic (22). Isolates collected from humans were generally sensitive to carbapenem. However, some bacteria isolated from human are multidrug-resistant $(5,45)$.

\section{Conclusions}

Some phenotypic properties of S. putrefaciens, such as enzymatic activity, adhesion capacity or iron absorption under environmental deficiency of this metal, may constitute the potential pathogenic factors of these microorganisms. Presented issues are very important for the aetiology of bacterial infections of fish, because these bacteria play an important role in the health status of fish through their ability to adapt and spread in the freshwater environment.

Further studies on the mechanisms of $S$. putrefaciens virulence are necessary. This could contribute to development of methods for prevention of infections. Spread of $S$. putrefaciens infection in freshwater fish have been observed in recent years, and therefore it is necessary to characterise this bacterium in relation to emerging risks, for prospective protection of the health of freshwater fish, environment, and humans.

Conflict of Interests Statement: The author declares that there is no conflict of interests regarding the publication of this article.

\section{References}

1. Al-Harbi A.H., Uddin M.N.: Seasonal variation in the intestinal bacterial flora of hybrid tilapia (Oreochromisniloticus x Oreochromis aureus) cultured in earthen ponds in Saudi Arabia. Aquaculture 2004, 229, 1, 37-44.
2. Al-Harbi, A.H., Uddin M.N.: Aerobic bacterial flora of common carp (Cyprinus carpio L.) cultured in earthen ponds in Saudi Arabia, J Appl Aquaculture 2008, 20, 108-119.

3. Bagge D., Hjelm M., Johansen C., Huber I., Gram L.: Shewanella putrefaciens adhesion and biofilm formation on food processing surfaces. Appl Environ Microbiol 2001, 67, 2319-2325.

4. Baj J., Markiewicz Z.: Biologia molekularna bakterii, PWN, Warszawa 2006, pp. 78-87.

5. Baruah F.K., Grover R.K.: Case report and literature review of carbapenem resistant Shewanella putrefaciens isolated from ascitic fluid. J Clin Diagn Res 2014, 8, DD01-DD02., doi:10.7860/JCDR/2014/9268.4819.

6. Borch E., Kant-Muermans M.L., Blixt Y.: Bacterial spoilage of meat and cured meat products. Int J Food Microbiol 1996, 33, 103-120.

7. Bowman J.P.: Genus XIII. Shewanella. In: Bergey's manual of systematic bacteriology, edited by Brenner D.J., Krieg N.R., Stale J.T., Springer, Michigan State University, 2005, 480-491.

8. Buller N.B.: Bacteria and fungi from fish and other aquatic animals: a practical identification manual. CABI Publishing, London 2014, pp. 168-176.

9. Decostere A., Haesebrouck F., Van Driessche E., Charlier G., Ducatelle R.: Characterization of the adhesion of Flavobacterium columnare (Flexibactercolumnaris) to gill tissue. J Fish Dis 1999, 22, 465-474.

10. Diaz J.H.: Skin and soft tissue infections following marine injuries and exposures in travelers. J Travel Med 2014, 21, 3, 207-213, doi: 10.1111/jtm.12115.

11. Gennari M., Campanini, R.: Isolamento e caratterizzazione di Shewanella putrefaciens da pesce fresco e alterato, carni fresche e alterate, prodotti lattiero-caseari, acqua e suolo. Industrial Aliment 1991, 30, 965-976, 988.

12. Gilardi G.L.: Cultural and biochemical aspects for identification of glucose-nonfermenting gram-negative rods. In: Nonfermentative gram-negative rods, edited by Gilardi G.L., Marcel Dekker, Inc. New York 1972, pp. 17-84.

13. Gram L., Huss H.H.: Microbiological spoilage of fish and fish products. Int J Food Microbiol 1996, 33, 121-137.

14. Gram L., Melchiorsen J.: Interaction between fish spoilage bacteria Pseudomonas sp. and Shewanella putrefaciens in fish extracts and on fish tissue. J Appl Bacteriol 1996, 80, 589-595.

15. Gram L.: Siderophore-mediated iron sequestering by Shewanella putrefaciens. Appl Environ Microbiol 1994, 60, 2132-2136.

16. Hider R.C., Kong X.: Chemistry and biology of siderophores. Natl Prod Rep 2010, 27, 637-657.

17. Holt H.M., Gahrn-Hansen B., Bruun B.: Shewanella algae and Shewanella putrefaciens: clinical and microbiological characteristics. Clin Microbiol Infect 2005, 11, 347-352.

18. Kang C.H., Shin Y., Jeon H., Choi J.H., Jeong S., So J.S.: Antibiotic resistance of Shewanella putrefaciens isolated from shellfish collected from the West Sea in Korea. Mar Pollut Bull 2013, 76, 85-86.

19. Kaszowska M.: Chemical structure and biosynthesis of lipopolysaccharide-important component of the cell envelope of Gram-negative bacteria. Postępy Hig Med Dosw 2004, 58, 333-342.

20. Khashe S., Janda J.M.: Biochemical and pathogenic properties of Shewanella alga and Shewanella putrefaciens. J Clin Microbiol 1998, 36, 783-787.

21. Korenevsky A.A., Vinogradov E., Gorby Y., Beveridge T.J.: Characterization of the lipopolysaccharides and capsules of Shewanella spp. Appl Environ Microbiol 2002, 68, 4653-4657.

22. Korun J., Akgun-Dar K., Yazici M.: Isolation of Shewanella putrefaciens from cultured European sea bass, (Dicentrarchus labrax) in Turkey. Rev Méd Vét 2009, 160, 532-536.

23. Kozińska A., Pękala A.: Characteristics of disease spectrum in relation to species, serogroups, and adhesion ability of motile aeromonads in fish. Sci World J 2012, doi:10.1100/2012/949358. 
24. Kozińska A., Pękala A.: First isolation of Shewanella putrefaciens from freshwater fish - a potential new pathogen of the fish. Bull Eur Assoc Fish Pathol 2004, 24, 199-203.

25. Ledyard K.M., Butler A.: Structure of putrebactin, a new dihydroxamate siderophore produced by Shewanella putrefaciens. J Biol Inorg Chem 1997, 2, 93-97.

26. Long H.F., Hammer B.W.: Classification of organisms important in dairy products: III. Pseudomonas putrefaciens. Iowa Agric Exp Stn Res Bull 1941, 285, 176-195.

27. MacDonell M.T., Colwell R.R.: Phylogeny of the Vibrionaceae and recommendation for two new genera, Listonella and Shewanella. Syst Appl Microbiol 1985, 6, 171-182.

28. Moule A.L., Wilkinson S.G.: Composition of lipopolysaccharides from Alteromonas putrefaciens (Shewanella putrefaciens). J Gen Microbiol 1989, 135, 163-173.

29. Nealson A.H., Scott J.: Ecophysiology of the genus Shewanella. In: The Prokaryotes, edited by Dworkin M., Falkow S., Rosenberg E., Schleifer K.H., Stackebrandt E., Springer, New York, 2006, pp. 1133-1151.

30. Nozue H., Hayashi T., Hashimoto Y., Ezaki T., Hamasaki K., Ohwada K., Terawaki Y.: Isolation and characterization of Shewanella alga from human clinical specimens and emendation of the description of S. alga Simidu et al., 1990, 335. Int J Syst Bacteriol 1992, 42, 628-634.

31. Owen R.J., Legros R.M., Lapage S.P.: Base composition, size and sequence similarities of genome deoxyribonucleic acids from clinical isolates of Pseudomonas putrefaciens. J Gen Microbiol 1978, 104, 127-138.

32. Pakingking R.J., Palma P., Usero R.: Quantitative and qualitative analyses of the bacterial microbiota of tilapia (Oreochromis niloticus) cultured in earthen ponds in the Philippines. World J Microbiol Biotechnol 2015, 31, 265-275.

33. Pękala A., Kozińska A., Paździor E., Głowacka H.: Phenotypical and genotypical characterization of Shewanella putrefaciens strains isolated from diseased freshwater fish. J Fish Dis 2015, 38, 283-293.

34. Qin L., Zhang X., Bi K.: A new pathogen of gibel carp Carassius auratus gibelio-Shewanella putrefaciens. Wei Sheng Wu Xue Bao 2012, 52, 558-565.

35. Qin L,, Zhu M., Xu L.: First report of Shewanella sp. and Listonella sp. infection in freshwater cultured loach, Misgurnus anguilticaudatus. Aquacult Res 2012, 45, 602-608.

36. Richards G.P., Watson M.A., Crane E.J., Burt I.G., Bushek D.: Shewanella and Photobacterium spp. in oysters and seawater from the Delaware Bay. Appl Environ Microbiol 2008, 74, 3323-3327.

37. Rusev V., Rusenova N., Simeonov R., Stratev D. Staphylococcus warneri and Shewanella putrefaciens coinfection in Siberian sturgeon (Acipenser baerii) and Hybrid sturgeon (Huso huso x Acipenser baerii). J Microbiol Exp 2016, 3, 1-4, doi: 10.15406/jmen.2016.03.00078.

38. Saeed M.O., Alamoudi M.M., Al-Harbi A.H.: A Pseudomonas associated with disease in cultured rabbitfish Siganus rivulatus in the Red Sea. Dis Aquat Organ 1987, 3, 177-180.

39. Semple K.M., Westlake D.W.S.: Characterization of ironreducing Alteromonas putrefaciens strains from oil field fluids. Can J Microbiol 1987, 33, 366-371.

40. Sharma K.K., Kalawat U.: Emerging infections: Shewanella a series of five cases. J Lab Phys 2010, 2, 61-65, doi: 10.4103/0974-2727.72150.

41. Soe C.Z., Codd R.: Unsaturated macrocyclic dihydroxamic acid siderophores produced by Shewanella putrefaciens using precursor-directed biosynthesis. ACS Chem Biol 2014, 9, 945-956.

42. Soe C.Z., Pakchung A.A., Codd R.: Directing the biosynthesis of putrebactin or desferrioxamine B in Shewanella putrefaciens through the upstream inhibition of ornithine decarboxylase. Chem Biodivers 2012, 9, 1880-1890.

43. Stenström I.M., Molin G.: Classification of the spoilage flora of fish, with special reference to Shewanella putrefaciens. J Appl Bacteriol 1990, 68, 601-618.

44. Tomás J.M.: The main Aeromonas pathogenic factors. ISRN Microbiol 2012, doi: 10.5402/2012/256261.

45. Vignier N., Barreau M., Olive C., Baubion E., Théodose R., Hochedez P., Cabié A.: Human infection with Shewanella putrefaciens and $S$. algae: report of 16 cases in Martinique and review of the literature, Am J Trop Med Hyg 2013, 89, 151-156.

46. Vogel B.F., Jorgensen K., Christensen H., Olsen J.E., Gram L.: Differentiation of Shewanella putrefaciens and Shewanella alga on the basis of whole-cell protein profiles, ribotyping, phenotypic characterization, and 16S rRNA gene sequence analysis. Appl Environ Microbiol 1997, 63, 2189-2199.

47. Zimke F., Höfle M.G., Lalucat J., Rossello-Mora R.: Reclassification of Shewanella putrefaciens Owen's genomic group II as Shewanella baltica sp. Nov. Int J Syst Bacteriol 1998, 48, 179-186. 